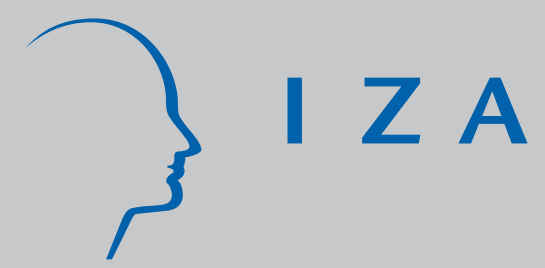

IZA DP No. 6080

The Effects of the Recent Economic Crisis on Social Protection and Labour Market Arrangements across Socio-Economic Groups

Gaetano Basso Matthias Dolls Werner Eichhorst Thomas Leoni Andreas Peichl

October 2011 


\title{
The Effects of the Recent Economic Crisis on Social Protection and Labour Market Arrangements across Socio-Economic Groups
}

\author{
Gaetano Basso
}

UC Davis

Matthias Dolls

IZA

Werner Eichhorst

$I Z A$

Thomas Leoni

WIFO

Andreas Peichl

IZA

Discussion Paper No. 6080

October 2011

IZA

P.O. Box 7240

53072 Bonn

Germany

Phone: $+49-228-3894-0$

Fax: +49-228-3894-180

E-mail: iza@iza.org

Any opinions expressed here are those of the author(s) and not those of IZA. Research published in this series may include views on policy, but the institute itself takes no institutional policy positions.

The Institute for the Study of Labor (IZA) in Bonn is a local and virtual international research center and a place of communication between science, politics and business. IZA is an independent nonprofit organization supported by Deutsche Post Foundation. The center is associated with the University of Bonn and offers a stimulating research environment through its international network, workshops and conferences, data service, project support, research visits and doctoral program. IZA engages in (i) original and internationally competitive research in all fields of labor economics, (ii) development of policy concepts, and (iii) dissemination of research results and concepts to the interested public.

IZA Discussion Papers often represent preliminary work and are circulated to encourage discussion. Citation of such a paper should account for its provisional character. A revised version may be available directly from the author. 


\section{ABSTRACT \\ The Effects of the Recent Economic Crisis on Social Protection and Labour Market Arrangements across Socio-Economic Groups*}

The Great Recession did not only affect European countries to a varying extent, its impact on national labour markets and on specific socio-economic groups in those markets also varied greatly. Institutional arrangements such as employment protection, unemployment insurance benefits and minimum income support, working time flexibility and wage setting played a crucial role in determining to what extent the economic crisis led to higher unemployment, wage cuts or income losses and rising poverty. As the crisis gained momentum, the action of automatic stabilisation mechanisms built into the national tax-benefit and social protection systems was accompanied by heterogeneous sets of discretionary policy measures. While these factors can explain cross-country variation in labour market developments, they also lead to an unequal distribution of economic risks associated with the crisis across socioeconomic groups. The present paper aims to investigate and assess to what extent the financial and economic crisis that hit the global economy in 2008-2009 impacted these labour market developments and to what extent different socio-economic groups were affected.

JEL Classification: $\quad \mathrm{H} 24, \mathrm{~J} 65, \mathrm{~J} 68$

Keywords: automatic stabilisers, unemployment protection, tax systems, Europe, Great Recession

Corresponding author:

Werner Eichhorst

IZA

P.O. Box 7240

53072 Bonn

Germany

E-mail: eichhorst@iza.org

\footnotetext{
* Andreas Peichl is grateful for financial support by Deutsche Forschungsgemeinschaft (DFG). Thomas Leoni acknowledges excellent research assistance by Lukas Tockner. The authors are grateful for comments received at the Second RDW Conference, Geneva, 6-8 July 2011.
} 


\section{Introduction}

The recent economic crisis did not only affect European countries to a varying extent, its impact on national labour markets and on specific socio-economic groups in those markets also varied greatly. Institutional arrangements such as employment protection, unemployment insurance benefits and minimum income support, working time flexibility and wage setting played a crucial role in determining to what extent the economic crisis led to higher unemployment, wage cuts or income losses and rising poverty (Bargain et al. 2011). As the crisis gained momentum, the action of automatic stabilisation mechanisms built into the national tax-benefit and social protection systems was integrated by heterogeneous sets of discretionary policy measures. While these factors can explain cross-country variation in labour market developments, they also lead to an unequal distribution of economic risks associated with the crisis across socio-economic groups. Accordingly, differences both across countries in their labour market response to the crisis, as well as within countries in the distribution of social and economic risks deserve careful scrutiny. Arguably the crisis has magnified pre-existing differences in macro-economic and labour market performance within the EU.

The present paper aims to investigate and assess to what extent the Great Recession that hit the global economy in 2008 impacted these labour market developments and to what extent different socio-economic groups were affected. We look the role of automatic stabilisers inherent in existing institutions as well as discretionary policy actions to tackle the crisis. After introducing a theoretical framework in section 2, the following section describes the existing institutions of unemployment protection and their effect on automatic stabilisation, pointing out their distributional consequences. Section 4 gives an overview about discretionary action taken and their effects across particular groups of workers whereas section 5 deepens the analysis of dual labour markets by presenting empirical evidence about access to unemployment benefits. Finally, section 6 concludes.

\section{Theoretical background}

It is beyond dispute that both the magnitude of the economic contraction during the crisis and its effects on labour markets were attenuated considerably by the work of automatic and discretionary stabilisation. Social protection contributed to limit the extent and duration of the recession and to stabilise labour markets and private consumption. This has occurred through two channels: Firstly, the social protection system has been acting as an automatic stabiliser on both the revenue side as well as the expenditure side of the general government budget. Secondly, discretionary action in the field of social and labour market policy has been pursued in most European economies. This includes a broad range of measures such as employment incentives, activation policies, higher benefits and increased transfers to low-income households. 
We should not overlook the possibility of large differences across countries in the stabilising impact of social protection. Such differences can be related to the structure and financing of the social protection system. Clearly, benefit entitlements, replacement rates and many other institutional characteristics lead us to expect a considerable degree of cross-country heterogeneity in automatic stabilisation.

Scandinavian and Continental European countries tend to have significantly larger mechanisms of automatic stabilisation than Southern and Central European countries. Due to the more progressive tax system and the more elaborated welfare state, the extent of automatic stabilisation in the EU is significantly larger than in the US. In spite of these countercyclical effects and the large size of automatic stabilisation in many European countries, an economic downturn such as the recent one is bound to affect households very asymmetrically. Job loss leads to a sharp decline in income for the unemployed and their families, at the same time other social groups are affected only marginally through stagnating real wages. The challenge for social policy which results from these asymmetric effects of the crisis is further enhanced by the presence of in-work poverty.

Automatic stabilisers in terms of social protection have the major advantage of providing income replacement immediately, i.e. when unemployment starts to rise, to those integrated into the benefit systems. They can however be ineffective with respect to securing employment and income (replacement) to those at the margin of the labour market. Unemployment insurance systems can be exclusive, as they do not equally protect each type of worker. While means-tested income support is generally available as a basic social security net in most EU Member States, this second tier of income assistance is not easily available, as stringent means-testing obliges households who experience prolonged unemployment first to run down their savings or even sell their home (OECD, 2011b). The extent of unemployment risks and the 'quality' of social protection provided to different socio-economic groups do not coincide, and in general, those most affected are the least protected. The extent of labour market dualism is of crucial importance in this respect, as "both automatic stabilizers and protection against job loss do not operate efficiently when there is a dualism in the labour market" (Boeri and Garibaldi 2009: 445). An optimum system of social protection should try to avoid this double disadvantage. This is why discretionary action to secure or facilitate employment as well as a discretionary expansion of benefit generosity or easing access to benefits can play a substantial role in reaction to crises. Direct public employment as well as employment subsidies to firms have the highest employment multipliers, as their job effects tend to be much higher than with any other measure.

Severe recessions can arguably lead to 'excessive' layoffs as the full economic cost of a displacement is higher in recessions when longer unemployment spells and harsher effects on individual careers can be expected (OECD, 2009). This hypothesis explains the strong interest in short-time working schemes and other forms of employment subsidies in the course of the recent crisis. Such schemes can be successful at avoiding cases where employers dismiss workers and thus waste human capital, although the jobs in question would be viable 
in the long-run.

\section{Institutional pattems of unemployment protection and EPL}

Systems of social protection can play a major role in buffering economic crises. The institutional set-up of social protection in place before a crisis affects the labour market and is therefore one major element to consider when comparing economic and social consequences to the Great Recession. First, social safety nets provide income security for individuals and households and thereby stabilise national demand in a phase of rising or high unemployment. Here, two elements have to be distinguished:

(i) the first tier of unemployment benefits stemming from unemployment insurance generally tied to contributions and substantial prior employment;

(ii) the second tier of means-tested minimum income support and related benefits for inactive or long-term unemployed people, including housing allowances etc.

Unemployment insurance benefits provide for income replacement in case of redundancies if certain national entitlement and availability criteria are met. Of particular importance is a sufficient employment record in terms of duration and earnings. While fixed-term contracts are often covered by unemployment insurance, holders of these types of jobs may not have a substantial entitlement to unemployment insurance benefits if waiting periods are not fulfilled due to interrupted employment spells. In addition, part-time employees or lowwage workers, while covered by the insurance, may only be able to draw very limited benefits from unemployment insurance due to the close link between earnings-related contributions and benefits. Furthermore, national systems of unemployment insurance vary in their coverage of different types of non-standard employment, such as self employment or marginal part time.

When comparing access criteria to unemployment insurance coverage and benefit receipt, it is particularly important to note that there are substantial minimum employment and contribution requirements which tend to leave labour market entrants with very short employment spells without substantial benefit claims. The same is true for self-employed in a number of countries and marginal part-time workers in Austria and Germany. Payment rates, as well as minimum and maximum benefits, also vary considerably, with a rather long maximum benefit duration but a relatively compressed distribution of benefits in countries such as Denmark and Belgium and mostly shorter, but more status-protecting, insurance benefits in France, Germany, Luxembourg or the Netherlands.

Apart from the more or less inclusive character of unemployment insurance, the generosity of unemployment insurance benefits is a crucial feature in assessing its role as an automatic stabiliser. To evaluate this, the extent of income replacement and the maximum duration of 
benefit have to be taken into account. In general, unemployment insurance benefits tend to be generous for those with a solid employment record and substantial earnings. However, unemployment insurance benefits may not be available for vulnerable groups who either do not meet the entitlement criteria or do not have substantial benefit claims but face a higher risk of unemployment due to a more difficult situation on the labour market before and during crises. This concerns particular groups such as (i) employees with fixed-term contracts and a short employment record, some of them labour market entrants, (ii) employees with low monthly earnings due to low hourly pay or part-time work, (iii) the self-employed. These groups tend to be affected by unemployment more than groups which are better integrated into the unemployment insurance system. But they may actually not have access to substantial insurance benefits in practice. Access to short-time work schemes, which provide an additional safeguard against unemployment, is also biased in favour of the core labour force, i.e. workers with specific skills and substantial tenure.

Minimum income support is a second and basic safety net providing basic social benefits for those not eligible for unemployment insurance or additional benefits in cases when unemployment insurance benefits do not suffice to avoid poverty. In general, the receipt of minimum income support depends on household-related means testing. It is not time-limited in European countries, but some age restrictions and availability criteria apply.

The generosity of minimum income support is more complex to assess, as other meanstested benefits can play a major role, in particular child-related and housing benefits. A reliable measure of basic income support generosity can be calculated as a combination of different relevant benefits available to typical target groups, including housing and child allowances after longer unemployment. Minimum income support is of particular importance to individuals who cannot rely on more generous insurance benefits. However, severe problems in terms of poverty arise if minimum income support is not available or unsuitable in providing poverty relief.

Finally, progressive taxes also contribute to automatic stabilisation, since lower income stemming from reduced earnings as a consequence of a reduction in wages or working-time are taxed less heavily than normal earnings. The income stabilisation coefficient (presented in Table 1 below), can be taken as an average measure of the progressiveness of the tax and contribution system referring to all income groups. Continental European and Scandinavian countries with well developed welfare states rank at the top, whereas Mediterranean and Central European countries show a less progressive element. 


\section{Measuring automatic stabilisation}

The tax and transfer system determines the way in which a given shock to gross income translates into a change in disposable income. This section is based on Dolls et al. (2010) and Dolls et al. (2011) and compares the magnitude and composition of automatic stabilisation between the US and Europe. We analyse the impact of automatic stabilisers using microsimulation models for 19 European countries (EUROMOD) and the US (TAXSIM). The microsimulation approach allows us to investigate the causal effects of different types of shocks on household disposable income, holding everything else constant and therefore avoiding endogeneity problems (see Bourguignon and Spadaro, 2006). Automatic stabilisers are usually defined as those elements of fiscal policy which mitigate output fluctuations without discretionary government action (see, e.g., Eaton and Rosen, 1980).

We run two controlled experiments of macro shocks to income and employment. The first is a proportional decline in household gross income by 5 per cent (income shock). This is the usual way of modelling shocks in simulation studies analysing automatic stabilisers. However, economic downturns typically affect households asymmetrically, with some households losing their jobs and suffering a sharp decline in income and other households being much less affected, as wages are usually rigid in the short-term. We therefore consider a second macro shock where some households become unemployed, so that the unemployment rate increases such that total household income decreases by 5 per cent (unemployment shock). ${ }^{2}$ We show that these two types of shocks and the resulting stabilisation coefficients can be interpreted as an average effective marginal tax rate (EMTR) for the whole tax benefit system at the intensive (proportional income shock) or extensive (unemployment shock) margin. As our measure of automatic stabilisation, we extend the normalised tax change (Auerbach and Feenberg, 2000) to include other taxes as well as social contributions and benefits. Our income stabilisation coefficient relates the shock absorption of the whole tax and transfer system to the overall size of the income shock. We take into account personal income taxes at all government levels, social insurance contributions and payroll taxes as well as transfers to private households such as unemployment benefits. Computations are conducted according to the tax benefit rules which were in force before 2008, in order to avoid an endogeneity problem resulting from policy responses after the start of the crisis.

Our results for the stabilisation coefficient vary considerably across countries, as can be seen from Figure 1. In the case of the income shock, we find the highest stabilisation coeffi-

\footnotetext{
2 The increase of the unemployment rate is modelled through re-weighting of our samples. The weights of the unemployed are increased while those of the employed with similar characteristics are decreased, i.e., in effect, a fraction of employed households is made unemployed. With this re-weighting approach, we control for several individual and household characteristics that determine the risk of becoming unemployed.
} 
cient for Denmark, where automatic stabilisers cushion 56 per cent of the shock. Belgium (53 per cent), Germany (48) and, surprisingly, Hungary (48) also have strong automatic stabilisers. The lowest values are found for Estonia (25 per cent), Spain (28) and Greece (29). With the exception of France, taxes seem to have a stronger stabilising role than social security contributions. In France, social security contributions are progressive and therefore have an important role for disposable income stabilisation.

Figure 1: Decomposition of income stabilisation coefficient for both scenarios - country ranking

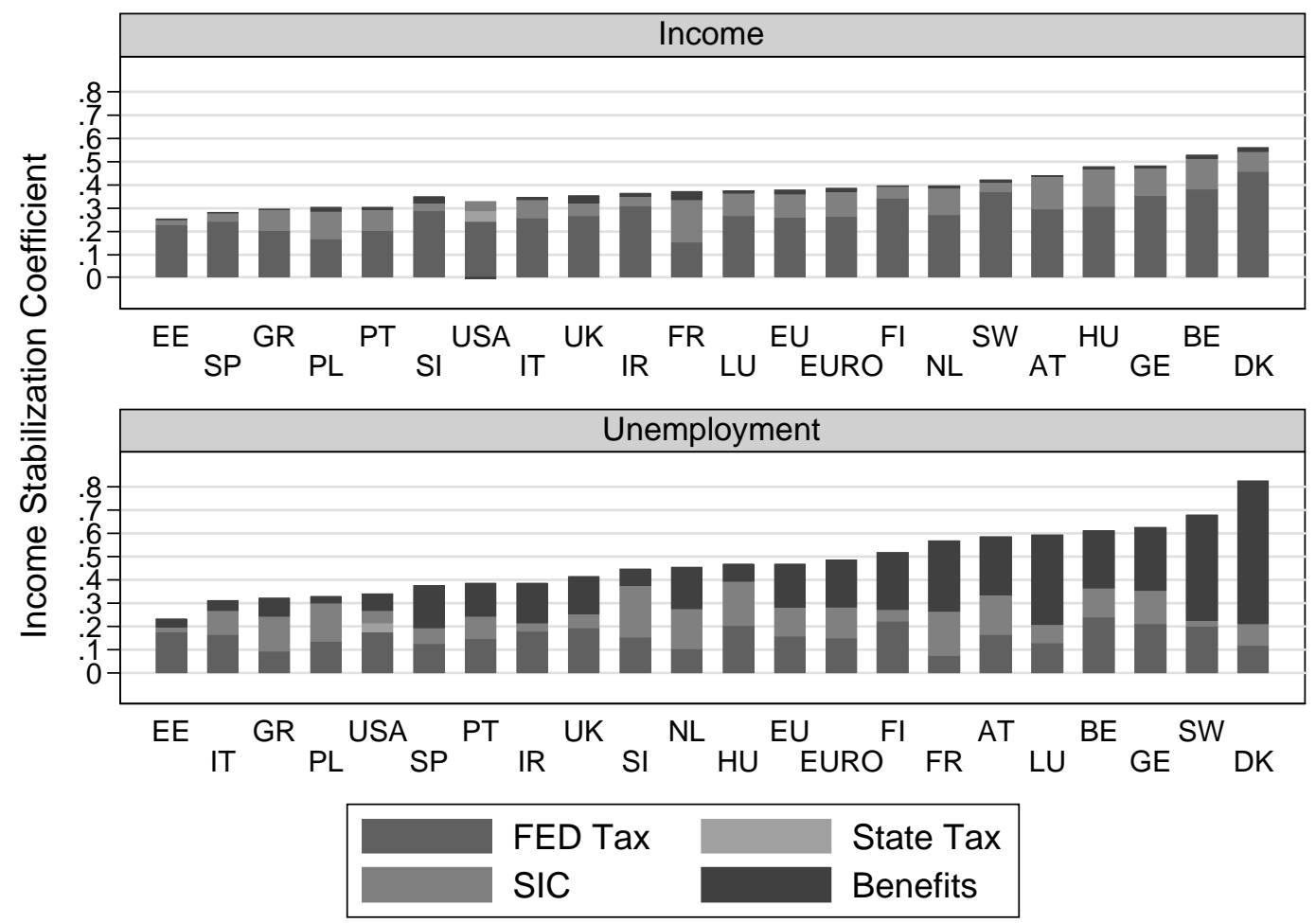

Source: Dolls et al. (2010).

In the case of the unemployment shock, the stabilisation coefficients are larger for the majority of countries. Again, the highest value emerges for Denmark ( 82 per cent), followed by Sweden (68), Germany (62) Belgium (61) and Luxembourg (59). The relatively low value of stabilisation from (unemployment) benefits in Finland compared to its neighbouring Nordic countries might be surprising at a first glance but can be explained with the fact that Finland has the least generous unemployment benefits of the Nordic countries (see Aaberge et al., 2000). Hungary (47 per cent) is now at the EU average due to the relatively low level of unemployment benefits which are important for disposable income stabilisation in case of an 
unemployment shock. At the other end of the spectrum, there are some countries with values below the US level of 34 per cent. These include Estonia (23 per cent), Italy (31), and, to a lesser extent, Poland (33).

Regarding distributional effects, Table 1 shows that in the case of the proportional income shock, the stabilisation coefficients are an increasing function of the income quantiles. This result is due to higher changes between market and disposable income for high income groups. It is worth mentioning that even a proportional tax would yield increasing coefficients for higher quantiles, i.e. progressivity of the income tax is not required for this result. In contrast to the increasing stabilisation by income quantile for the income shock, stabilisation results for the unemployment shock follow a somewhat different pattern as demonstrated in Table 2. Here, with the exception of some Eastern and Southern European countries, we also find high stabilisation for the lowest income groups. As the unemployment shock is modelled through re-weighting of our sample, taking into account individual characteristics of the unemployed, a large part of the newly unemployed comes from lower income quantiles. The fact that tax and transfer systems in countries such as Estonia, Greece, Italy, Poland, Portugal, Slovenia or Spain provide only weak stabilisation for low income groups can be explained by rather low unemployment benefits in these countries.

Table 1: Stabilisation of income groups - Proportional Income Shock

\begin{tabular}{|l|c|c|c|c|c|c|}
\hline & TAU & Q1 & Q2 & Q3 & Q4 & Q5 \\
\hline Austria & 0.439 & 0.023 & 0.045 & 0.072 & 0.107 & 0.192 \\
\hline Belgium & 0.527 & 0.022 & 0.051 & 0.082 & 0.128 & 0.244 \\
\hline Denmark & 0.558 & 0.017 & 0.046 & 0.088 & 0.135 & 0.273 \\
\hline Estonia & 0.253 & 0.010 & 0.019 & 0.036 & 0.063 & 0.126 \\
\hline Finland & 0.396 & 0.010 & 0.031 & 0.063 & 0.099 & 0.192 \\
\hline France & 0.370 & 0.032 & 0.036 & 0.053 & 0.079 & 0.171 \\
\hline Germany & 0.481 & 0.019 & 0.045 & 0.072 & 0.116 & 0.228 \\
\hline Greece & 0.291 & 0.004 & 0.015 & 0.033 & 0.063 & 0.176 \\
\hline Hungary & 0.476 & 0.029 & 0.041 & 0.056 & 0.097 & 0.254 \\
\hline Ireland & 0.363 & 0.009 & 0.026 & 0.048 & 0.084 & 0.197 \\
\hline Italy & 0.346 & 0.010 & 0.035 & 0.051 & 0.077 & 0.173 \\
\hline Luxembourg & 0.374 & 0.019 & 0.022 & 0.042 & 0.082 & 0.208 \\
\hline Netherlands & 0.397 & 0.020 & 0.040 & 0.062 & 0.093 & 0.182 \\
\hline Poland & 0.301 & 0.017 & 0.032 & 0.047 & 0.060 & 0.145 \\
\hline Portugal & 0.303 & 0.012 & 0.013 & 0.029 & 0.055 & 0.194 \\
\hline Slovenia & 0.317 & 0.022 & 0.010 & 0.008 & 0.037 & 0.240 \\
\hline Spain & 0.277 & 0.006 & 0.020 & 0.036 & 0.062 & 0.153 \\
\hline Sweden & 0.420 & 0.022 & 0.041 & 0.066 & 0.096 & 0.196 \\
\hline United & 0.352 & 0.010 & 0.034 & 0.047 & 0.079 & 0.182 \\
\hline
\end{tabular}


Kingdom

Source: Dolls et al. (2011).

Table 2: Stabilisation of income groups - Unemployment Shock

\begin{tabular}{|l|c|c|c|c|c|c|}
\hline & TAU & Q1 & Q2 & Q3 & Q4 & Q5 \\
\hline Austria & 0.585 & 0.111 & 0.094 & 0.069 & 0.130 & 0.181 \\
\hline Belgium & 0.612 & 0.143 & 0.087 & 0.067 & 0.101 & 0.215 \\
\hline Denmark & 0.823 & 0.095 & 0.189 & 0.166 & 0.196 & 0.177 \\
\hline Estonia & 0.233 & 0.062 & 0.019 & 0.019 & 0.041 & 0.091 \\
\hline Finland & 0.519 & 0.118 & 0.057 & 0.074 & 0.093 & 0.176 \\
\hline France & 0.568 & 0.102 & 0.102 & 0.088 & 0.092 & 0.185 \\
\hline Germany & 0.624 & 0.144 & 0.078 & 0.090 & 0.118 & 0.193 \\
\hline Greece & 0.322 & 0.016 & 0.031 & 0.040 & 0.071 & 0.164 \\
\hline Hungary & 0.467 & 0.091 & 0.045 & 0.048 & 0.071 & 0.212 \\
\hline Ireland & 0.387 & 0.101 & 0.049 & 0.044 & 0.061 & 0.132 \\
\hline Italy & 0.311 & 0.011 & 0.021 & 0.047 & 0.081 & 0.151 \\
\hline Luxembourg & 0.593 & 0.148 & 0.177 & 0.056 & 0.070 & 0.142 \\
\hline Netherlands & 0.452 & 0.123 & 0.048 & 0.054 & 0.088 & 0.140 \\
\hline Poland & 0.329 & 0.031 & 0.035 & 0.048 & 0.066 & 0.150 \\
\hline Portugal & 0.386 & 0.014 & 0.005 & 0.040 & 0.075 & 0.252 \\
\hline Slovenia & 0.431 & 0.045 & 0.038 & 0.056 & 0.083 & 0.210 \\
\hline Spain & 0.376 & 0.038 & 0.049 & 0.065 & 0.076 & 0.148 \\
\hline Sweden & 0.678 & 0.160 & 0.109 & 0.109 & 0.110 & 0.190 \\
\hline United & 0.415 & 0.142 & 0.034 & 0.030 & 0.060 & 0.150 \\
\hline Kingdom & & & & & & \\
\hline Sourc: & & & & & &
\end{tabular}

Source: Dolls et al. (2011).

\section{The contribution of discretionary measures}

During the crisis, policy-makers implemented a number of discretionary reforms to social protection systems (see table 3 ). The first phase of discretionary anti-crisis interventions was characterised by a number of reforms strengthening the current unemployment insurance benefit system, in particular by easing access or improving benefit generosity for nonstandard workers who had been made redundant. Measures that went in this direction included the reduction of qualifying times for unemployment insurance (e. g. Sweden), the prolongation of unemployment benefits entitlement (e. g. Romania) or the increase in replacement rates for specific sub-groups of the workforce that were previously less covered than core workers (e. g. Luxembourg, and again Sweden). This does not preclude, however, that subsequent reforms in a phase of austerity will lead to further dualisation in the sense 
that benefit cuts may address non-standard workers, i.e. workers with 'atypical' contracts, more than social security systems of the core workforce. In most countries, social protection was increased beyond the realm of unemployment benefits, with a number of measures targeted at families with children and households exposed to poverty risks. To give only a few examples: In Germany tax-free child allowances and child benefits were increased, while in Austria the child tax credit was increased, a tax-free child allowance was introduced and the costs of childcare, including kindergarten, were made tax-deducible from the income of one of the parents. In France, households subject to the first tax bracket benefited from a substantial reduction in their tax liability, while on a similar note Spain increased the tax credit for low-income households.

As can be seen from the table, measures to maintain or facilitate (re)employment featured even more prominently in labour market packages implemented during the crisis. The most wide-spread reaction has been to step up efforts to train both employed and unemployed workers and to intensify job search assistance and overall public employment services capacities (Cazes et al., 2009). 23 out of 27 EU Member States took steps to improve job placement and invest in re-training, while 19 countries reinforced activation. Some countries also implemented other types of policy changes or new initiatives, such as increasing incentives for entrepreneurship. This response represents a discretionary component of stabilisation, complementing the automatic stabilisation through mainly passive labour market expenditure discussed in the previous section. Although overall expenditure on unemployment is highly counter-cyclical, in the past significant differences between passive and active measures could be observed, especially as to the proportionality with which spending reacts to changes in the absolute number of unemployed. Estimates based on the historically typical reaction of spending indicate that in the OECD countries per person resources for labour market policies do not raise in proportion to the increase in unemployment (OECD, 2009, 2010). This finding is driven by a sharp decline in per person resources for active measures. As we would expect, unemployment benefits move proportionally with the number of unemployed. This implies that during a recession public employment services are confronted with significant constraints in assisting unemployed people and that they have to ration active measures. This finding can be linked to the difficulty to adjust active labour market policies quickly in the face of a downturn. Spending on unemployment is less responsive to cyclical unemployment than to trend developments in the unemployment rate. With respect to activating measures, such as training or job search assistance, capacity constraints may be an important barrier to rapid expansion of service offerings. Looking at the cyclicality of more detailed programme categories the OECD finds that expenditures on training have been totally unresponsive to cyclical unemployment, whereas they represent the category of active measures that has been most responsive to changes in trend unemployment. Conversely, direct job-creation schemes display the opposite pattern, i.e. a strong correlation with cyclical unemployment and none with trend unemployment (OECD, 2009). 
Another set of policies was geared at encouraging flexible working time, thus enhancing internal flexibility, and more in general at cutting labour costs. Some measures were quite innovative, such as Austria's attempt to encourage further education and skill formation through an attractive educational leave scheme. However, in this area, short-time working schemes to prevent dismissal were the most prominent and by far the most widely used measure. Figure 2 shows the extent to which short-time work schemes were used in Europe during the economic crisis. Generosity of the system and easiness of access can basically explain the strong variation across countries in interaction with the specific motivation of employers to rely on short-time work. The annual average stock of short-time workers was more than 5 per cent of all employees in Belgium in 2009 and around 3 per cent in Italy, Germany and Luxembourg. Apart from Belgium's - and, to a lesser extent, Italy's and France's - reliance on short-time work, which predated the crisis, all countries experienced a marked increase from very low levels. In many countries, short-time working schemes were already in place before the crisis but had been used scarcely. During the crisis their attractiveness was enhanced by increasing their flexibility and the amount of public subsidization. These steps were taken because short-time work schemes are associated with strong positive employment effects, substantially higher than the indirect employment effects that result from stabilisation of GDP.

There is still incomplete evidence with respect to the distributional aspects related to these effects. Numerous measures implemented during the crisis were targeted at low-income households and at marginal segments of the workforce. In spite of the many crisis related measures that were implemented to strengthen income replacement programmes, the crisis exposed significant gaps in the safety nets for the unemployed (OECD, 2011, see also Section 5). The available information suggests also that a significant share of the resources that were mobilized to counteract the crisis actually benefited primarily middle segments of the income distribution as well as workers with regular contracts. Discretionary social policy was thus probably not sufficient to absorb the asymmetric impact of the crisis on the weakest groups of the labour force and of society.

One piece of evidence that supports this mixed (albeit admittedly preliminary) assessment comes from an analysis of the structure of discretionary social policy. In relative terms, discretionary measures on the revenue side represented the bulk of the fiscal stimulus injected during the crisis: Approximately $70 \%$ of all resources concerned cuts of government revenue, whereas only $30 \%$ were effective on the expenditure side. With the exception of a few countries such as Sweden and Denmark, most countries were reluctant to increase public expenditure substantially. Accordingly, tax cuts to support private households' income and consumption represented the quantitatively most important part of discretionary fiscal stimuli. Most likely the distributional effects of these tax cuts were heterogeneous across countries. In some instances, fiscal measures on the revenue side focused on low-income groups and consisted of tax credits (e.g. Spain) or tax reliefs targeted at households in the lowest tax brackets (e.g. France). Many tax reductions and other measures such as reduc- 
tions in social security contributions and labour costs, on the other side, had a much broader focus and favoured primarily those segments that shoulder the largest share of the tax burden. To give a few examples: In Belgium and Luxembourg, the most costly fiscal measures consisted in an indexation of tax brackets. In Germany and Austria, comprehensive tax reforms including increased personal allowances and tax relief for families were implemented. Finland introduced, among other things, a tax cut for wage earners and pensioners across all income groups as well as tax deductions for house renovations.

A similar picture emerges from a look at measures implemented in the realm of the labour market and employment. Numerous measures, both in the active and the passive dimension of labour market policy, were explicitly targeted at marginal workers, characterised by a high risk of job loss and by low levels of social protection. Measures to improve the employment perspective of groups that face high unemployment rates (such as young and old workers) also featured in most labour market packages adopted during the crisis. The most prominent measure to support employment - short-time work schemes - was however not symmetric across segments of the labour force. In principle, incentives to reduce working time represent a way to spread the burden of adjustment more equitably across the work force: Whereas reliance on layoffs concentrates the costs of adjustment on a relatively small number of workers, short-time arrangements lead to an adjustment through the hours worked, not the persons in employment (Abraham and Houseman, 1994). At the same time, short-time work arrangements represent only a partial subsidization of the costs associated by firms with keeping workers in employment. They are attractive for firms only when the subsidy reduces the costs of employment to the point where they become lower than the costs that would result from a layoff. Accordingly, short-work schemes are most effective for jobs characterized by high search costs (for instance due to skill shortage in the labour market or a high degree of firm-specific knowledge) or high separation costs (as in the case of high employment protection).

It is thus not surprising that short-time work arrangements were wide-spread in skilled segments of the labour force and among workers with regular contracts. Low-qualified workers, who are comparatively easy to find on the labour market and who carry out tasks with a low level of firm-specific knowledge, as well as marginal workers with low levels of employment protection, did not benefit significantly from the public subsidization of working time reduction. In their evaluation of short-time work during the recession, Cahuc and Carcillo (2011) reach the conclusion that short-time work programmes indeed stabilised employment and reduced unemployment. According to the authors, however, short-time work had a positive impact on permanent employment only, but not on temporary employment. Hijzen and Venn (2011) and OECD (2010) also find that short-time work arrangements were very beneficial to the overall employment situation and that they were associated with only low deadweight losses, but also that their positive impact was limited to workers with permanent contracts, thereby further increasing labour market segmentation. 
Table 3: Discretionary measures

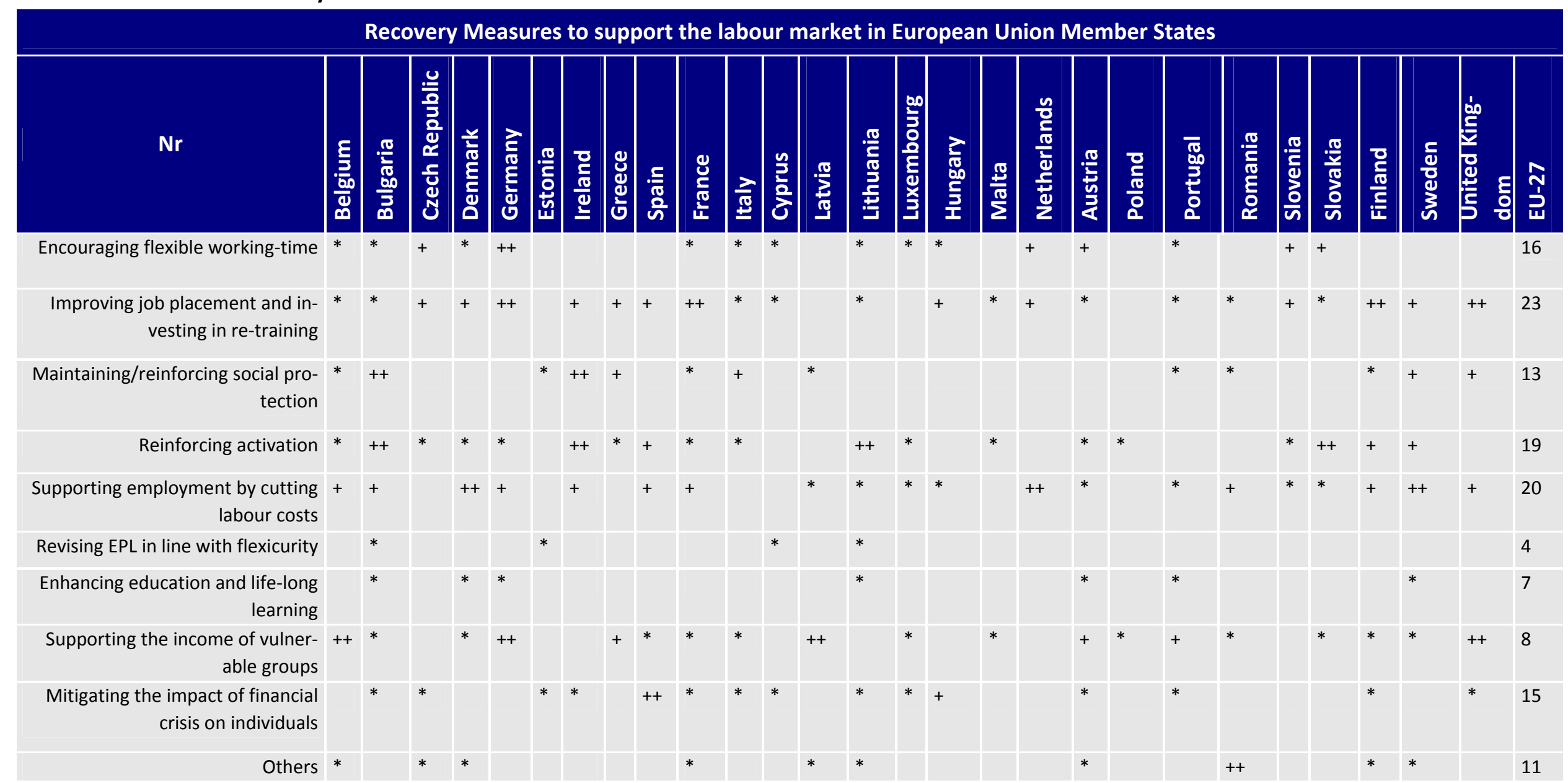

++ highly significant measures taken, + somewhat significant measures taken, *measures taken, EU-27 column: number of countries which implemented the corresponding measure. Source: European Commission, 2009; OECD, 2010b. 


\section{Unemployment protection in dual labour markets}

In the previous sections we analysed to which extent automatic stabilisation should have occurred during the recent crisis and how people should have been protected by automatic stabilisers and by discretionary measures. In this section we further analyse which group of workers has been most affected by the labour crisis and how the labour market effects differ across groups in different countries, pointing in particular to the unequal distribution of labour market risks and social protection. Actually, there have been marked differences in access to benefits received both within and across countries. This asymmetric figure seems to be, at least partially, a consequence of the process of dualisation of the labour market in many European countries. As already documented by the IMF (World Economic Outlook, IMF, 2010), these asymmetric reforms caused a dramatic increase of the use of fixed-term workers, which did not exist in most countries only two decades ago. Countries with the strictest provisions for regular contracts experienced a boom in the share of fixed-term (temporary) contracts in total dependent employment. Indeed, the increasing use of temporary workers has not only resulted in dual-track, two-tier labour arrangements, but has also blurred the boundary between dependent employment and self-employment.

Many European countries entered into the recent crisis with a much segmented labour market. A preliminary way to look at this is by analysing the OECD EPL index, the widely used measure of the severity of employment protection legislation based on an assessment of national regulations. The EPL index shows a clear pattern for all the European countries. The reforms since 1990 (see IMF (2010), and Eichhorst et al., 2010) have been broadly aimed at reducing dismissal costs, notably in countries that already had the strictest standards. Moreover, there is evidence that (see IMF (2010), and Eichhorst et al., 2010) many European countries (notably Belgium, Denmark, Germany, Greece, Italy, Portugal, Spain and Sweden) carried out EPL reforms involving a change in the overall index exceeding two thirds of the cross-country standard deviation in the index in 1990. We also observe a converging path: the contemporaneous decline in the average of the overall index for European OECD countries and of the cross-country standard deviation of this indicator.

However, the measurement of dualism is a non-trivial exercise because the two-tier nature of the labour market affects many dimensions, from share of temporary workers among the employees to the probability of transition between labour market status and, finally, to wage differentials. These reflect the stronger bargaining power of regular workers and the fact that workers with flexible contracts are not covered by EPL. Going into more detail, we can give a broad idea of what European countries labour markets looked like in 2008 with respect to dualism. In Figure 2 we plot the share of temporary workers against the level of the EPL regular index, on the left hand side, and then the transition probability against the same EPL index, on the right hand side. 
Both the measures are highly correlated with the level of EPL. In particular, the correlation coefficient between the share of temporary workers and EPL is 0.81 , while the transition probability from temporary to permanent positions is negatively correlated with the severity of employment protection legislation $(\rho=-0.72)$.

\section{Figure 2: EPL, temporary workers and transition probability from temporary to permanent positions in Europe.}
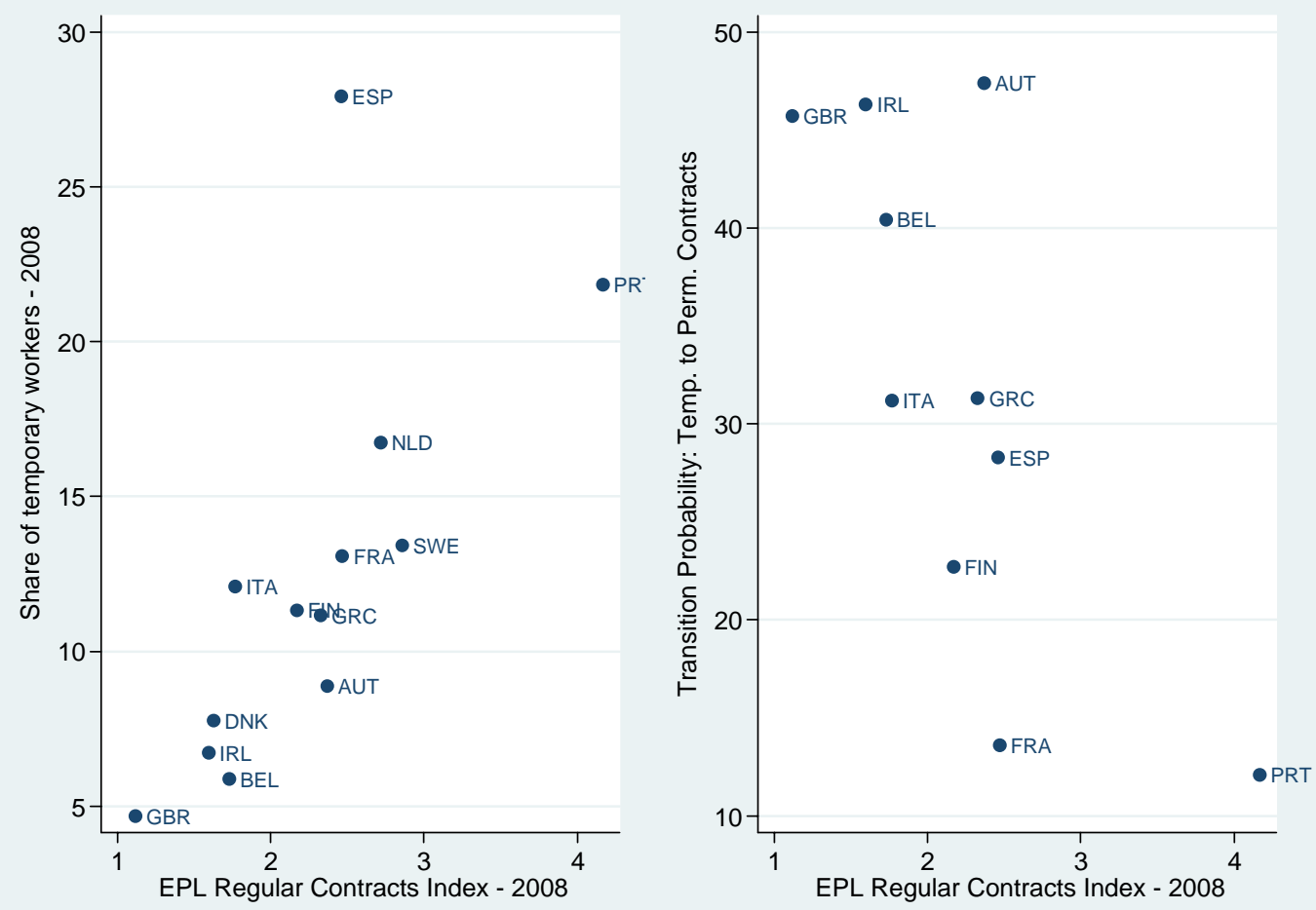

Source: OECD and Eurostat labour force statistics 2008 (left panel); OECD and EU-SILC 2004-2007 longitudinal component (right panel).

We can summarise in the following table, similar to that published by IMF (2010), the four main variables mentioned through which we can measure labour market dualism. The wage premium (first column) can be compared with the share of fixed-term employees in total dependent employment in the second column. ${ }^{3}$ The rankings between the two columns differ (the Spearman correlation coefficient between the two measures of dualism is 0.41 ), but the United Kingdom stands out as having the least disparity according to both measures.

\footnotetext{
${ }^{3}$ The premium can be estimated as the coefficient of a dummy variable on permanent contracts, in a (monthly) wage regression of male dependent employment, controlling for education and tenure:

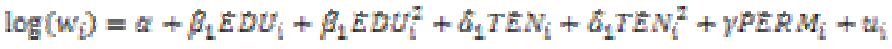

where indexes individuals and $P E R M$ is the dummy variable for having a permanent contract.
} 
Finally, using the new version of the Social Reforms database, assembled by the Fondazione Rodolfo Debenedetti and the Institute for the Study of Labor (IZA), we can identify the percentage of EPL reforms which covered only part of the labour force (two-tier reforms) in the last 30 years in European countries. The share of these reforms among the total of employment protection reforms varies consistently. However, half of the countries covered in the database have a share of two-tier reforms which is higher than 50 per cent (notably, Italy, Austria and Spain exceed 70 per cent).

Table 5: Summary of dualism measures in European countries

\begin{tabular}{lcccc}
\hline \hline & $\begin{array}{c}\text { Percentage } \\
\text { wage pre- } \\
\text { mium for } \\
\text { permanent }^{\text {contracts }}{ }^{\text {a }}\end{array}$ & $\begin{array}{c}\text { Share of temp. } \\
\text { contracts } \\
\text { among em- } \\
\text { ployees }^{\text {b }}\end{array}$ & $\begin{array}{c}\text { Transition } \\
\text { prob. from } \\
\text { temp. to } \\
\text { perm. con- } \\
\text { tract }^{\text {c }}\end{array}$ & $\begin{array}{c}\text { Percentage of } \\
\text { two-tier EPL } \\
\text { reforms }\end{array}$ \\
\hline Austria & 20.1 & 8.9 & 47.4 & 84.6 \\
Belgium & 13.9 & 8.6 & 40.4 & 75.0 \\
Denmark & 17.7 & 8.6 & & 55.6 \\
Finland & 19.0 & 15.9 & 22.7 & 42.9 \\
France & 28.9 & 15.2 & 13.6 & 41.2 \\
Germany & 26.6 & 14.6 & & 69.2 \\
Greece & 10.3 & 10.9 & 31.3 & 53.8 \\
Ireland & 17.8 & 8.0 & 46.3 & 38.5 \\
Italy & 24.1 & 13.2 & 31.2 & 86.7 \\
Netherlands & 35.4 & 17.9 & & 43.7 \\
Portugal & 15.8 & 22.4 & 12.1 & 35.7 \\
Spain & 16.9 & 31.7 & 28.3 & 70.6 \\
Sweden & 44.7 & 17.2 & & 40.0 \\
United King- & 6.5 & 5.7 & 45.7 & 16.0 \\
dom & & & & \\
\hline \hline
\end{tabular}

Sources: a. EU SILC (mid '90s ECHP estimates for Netherlands); b. Eurostat labour force statistics, 2007; c. Estimated from matched records of EU SILC for 2004-07 (last data available); d. fRDB - IZA Social Reforms Database (percentage among institutional reforms). Partially drawn from IMF, 2010.

The share of temporary contracts steadily increased before the 2008-2009 recession in countries with stricter EPL. However, temporary workers experienced the majority of recession-related job losses, and hence this share has been falling in the recession. The most representative country is Spain, where temporary workers declined by 22.9 per cent during the period 2008 quarter 2 to 2010 quarter 2 (compared with 9.6 per cent for total employment); almost the same happened by 9.6 per cent in Italy (compared with 2.4 per cent). European Union (15 countries) average reported a loss of 6.2 
per cent, and Sweden was slightly below the average (a loss of 5.9 per cent, while total employment dropped by only 1.6 per cent). Quite differently, France experienced a lot of quarterly variation in temporary employment, while total employment loss during the crisis is around 1 per cent (and it slightly changes comparing different quarters): the temporary employment drop was -0.9 per cent in the period $2008 q 2-2010 q 2$, but 8.6 per cent if comparing $2008 q 2$ with $2010 q 1 .{ }^{4}$

In the same period Germany outperformed the other countries: temporary employment was stable, -0.1 per cent between $2008 q 2$ and $2010 q 2$. As many economists have already noticed (among others Boeri and Bruecker (2011) and OECD (2010)) the German case is quite different: the total employment during the crisis period remains unchanged, and no significant change in the share of temporary contracts can be noticed during and after the crisis.

The following figures show the rise and fall and rise again of temporary contracts in some European countries from 2005 and 2010. Most of the countries experienced a drop in the mean share as a consequence of both the recession and of the severity of EPL for permanent contracts. However, once the recession was over the majority of new hires took place with temporary contracts. This explains the new rise in the share of temporary contract after 2009 in all the countries examined, except in Spain where recovery is still unsure.

Table 6: Share of temporary workers as a percentage of total dependent employment

\begin{tabular}{lcccccc}
\hline \hline & $\mathbf{2 0 0 5}$ & $\mathbf{2 0 0 6}$ & $\mathbf{2 0 0 7}$ & $\mathbf{2 0 0 8}$ & $\mathbf{2 0 0 9}$ & $\mathbf{2 0 1 0}$ \\
\hline European Union (15 countries) & 14.4 & 14.9 & 14.9 & 14.5 & 13.8 & 14.1 \\
France & 14.1 & 14.9 & 15.2 & 15.0 & 14.4 & 15.1 \\
Germany & 14.2 & 14.5 & 14.6 & 14.7 & 14.5 & 14.7 \\
Italy & 12.3 & 13.1 & 13.2 & 13.3 & 12.5 & 12.8 \\
Portugal & 19.5 & 20.6 & 22.4 & 22.9 & 22.0 & 23.0 \\
Spain & 33.4 & 34.1 & 31.7 & 29.3 & 25.5 & 25.0 \\
Sweden & 15.7 & 17.0 & 17.2 & 15.8 & 14.9 & 15.4 \\
& & & & & & \\
\hline \hline
\end{tabular}

Source: Eurostat labour force statistics, 2005-2010.

We have so far seen that some countries suffer an internal division of the labour market more than others: this phenomenon is relatively recent. One of the main dimensions to be investigated deals with the characteristics of individuals holding a temporary contract. In this section, we try to shed some light on this issue by using the information contained in the European Union Survey on Income and Living Conditions and on the last release of European Labour Force Survey micro database.

\footnotetext{
${ }^{4}$ The source of these data is Eurostat labour force statistics, quarterly detailed survey.
} 
The following figure illustrates the age of workers: the reported measures are the odds ratio of the share temporary workers to that of permanent workers with respect to age class. By construction, if the distribution of age classes were equal across the two worker groups, the ratios would add to 1 . On the contrary, if the ratio is higher than 1, then temporary workers would be over represented. As it is clear from the picture, temporary contracts were overrepresented among young (those aged less than 25) in dual countries before the crisis. ${ }^{5}$ However, while in 2008-2009 the odds for the youngest workers dropped below 1, in 2010 it reached an higher level than the pre-crisis one.

Figure 3: Temporary workers: odds ratios by age in dual and non-dual countries

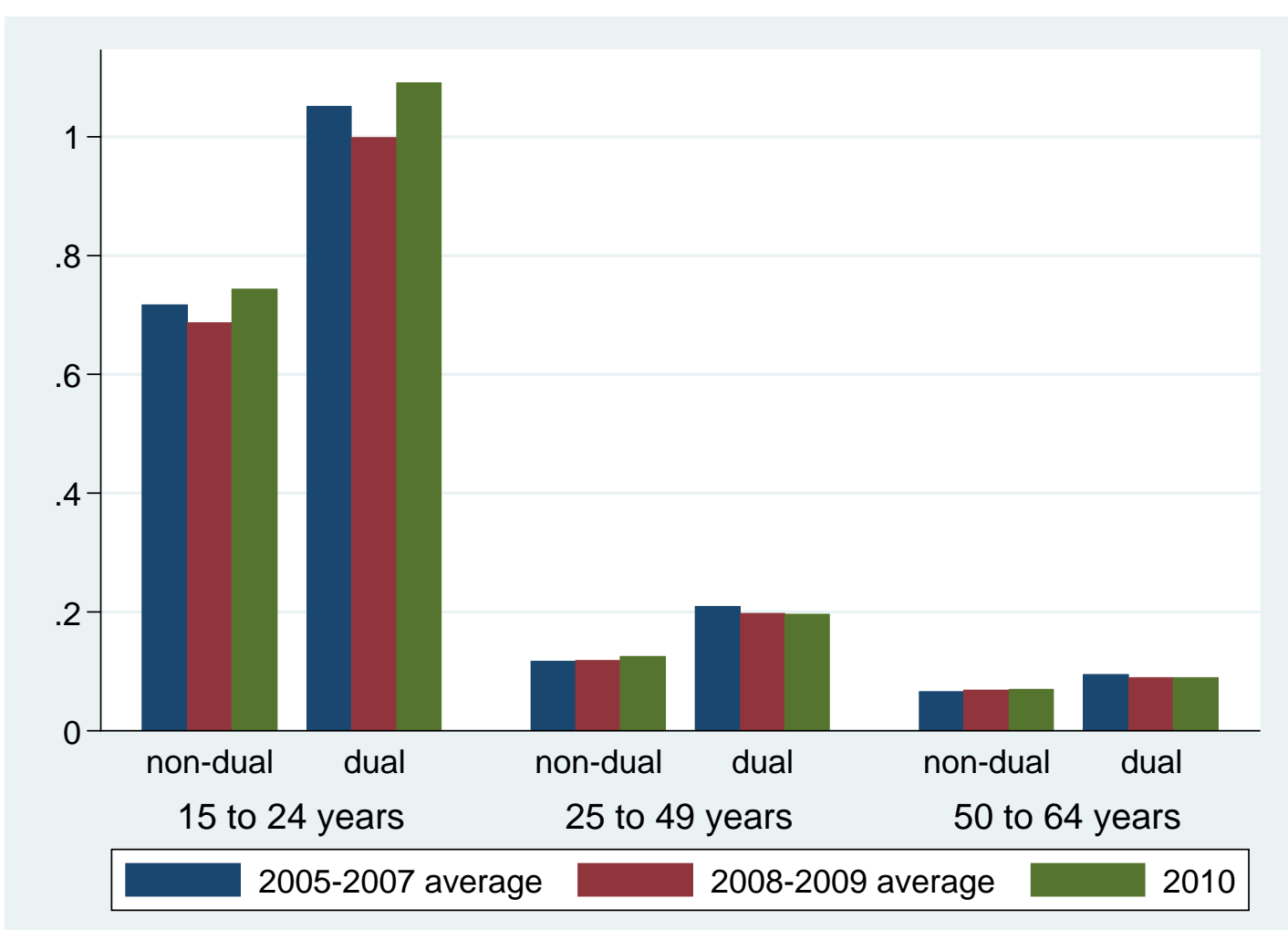

Source: Eurostat labour force statistics, 2005-2010.

Focusing more on educational attainment, we built a measure of concentration of workers, based again on odds ratios, which consider both temporary contracts and unemployment incidence. The measure is the following:

\footnotetext{
${ }^{5}$ We consider as dual countries France, Greece, Italy, Portugal, Spain, Sweden as a consequence of rankings of the previous table in this section. Non-dual countries are Austria, Belgium, Denmark, Germany, Finland, Ireland and United Kingdom. European average always refers to European Union 15 countries average, a part from Luxembourg.
} 
- Incidence of temporary workers: $\frac{\text { temp }_{\text {skill }} / \text { empl } l_{\text {skill }}}{\text { temp/empl }}$

- Incidence of unemployment: $\frac{u_{\text {skill }} / l f_{\text {skill }}}{u / l f}$

where skill stands for primary, secondary or tertiary according to aggregated ISCED levels of education.

In the following figure, we plot (2) (on the y axis) versus (1) (on the right axis). The result is hardly surprising: low skilled workers are highly concentrated in the top right quadrant, meaning that they are over represented among both unemployed and temporary workers. On the contrary, high skilled workers are mostly on the bottom left quadrant.

Figure 4: Incidence of temporary workers and unemployed by educational attainment

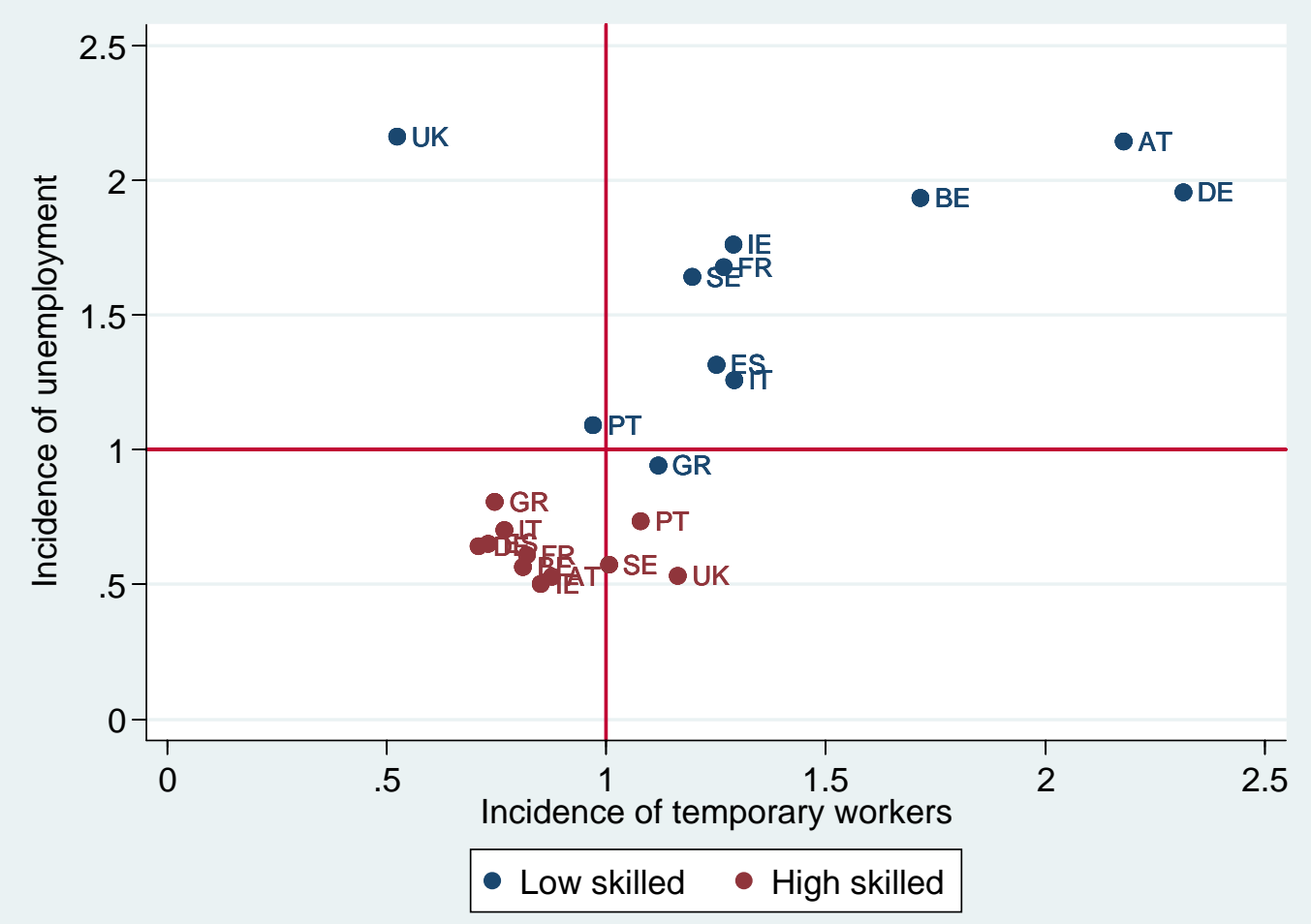

Source: EU-SILC, 2008.

A main concern regarding the use of temporary jobs, is the extent and the coverage of unemployment benefits, especially during recession periods. Some preliminary evidence suggests that the extent of unemployment risks and social protection do not coincide: national benefit schemes hardly cover former temporary workers with unemployment insurance. However, there is little empirical literature so far that covers 
this topic. Figari et al. (2011) has recently analysed the extent of social protection using EUROMOD simulations in five European countries, while D'Amuri (2011) has carried out an interesting analysis of the effects of the current crisis on the Italian labour market.

The main reason why there is so little literature is a lack of data. However, we know from above that some countries are more dual than others. So, we can analyse the coverage and extent of unemployment benefits both on age and on educational attainment dimensions, considering separately dual and non-dual countries.

Figure 5: Coverage of unemployment benefits by age: non-dual and dual countries

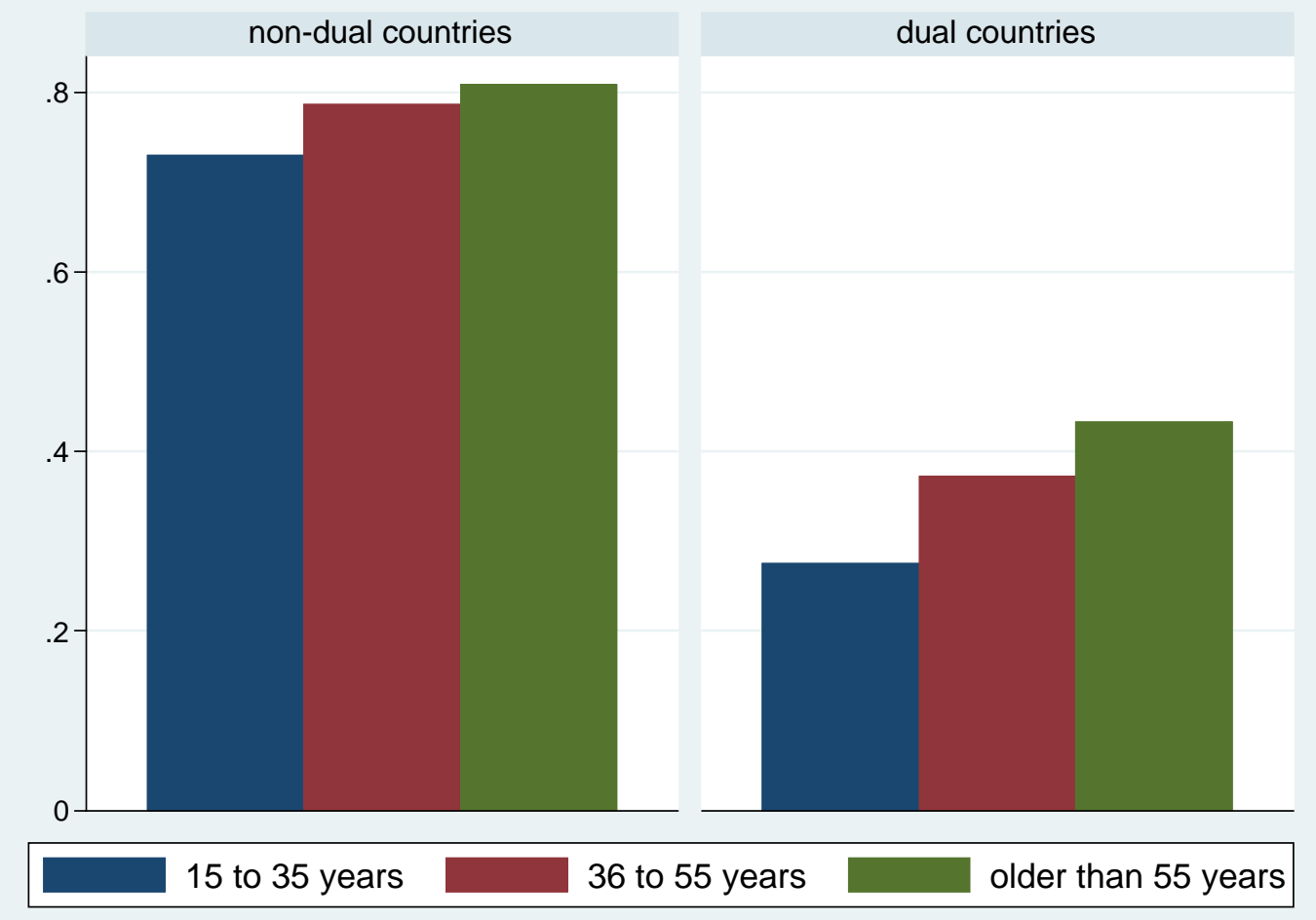

Source: European Survey on Income and Living Condition, 2008.

The figure above suggests that younger people have much less coverage than older workers both in non-dual and dual countries, but in the latter group the difference between the share of young and middle-aged covered is very high (around 10 percentage points, from 27.5 to 37.2 per cent). This suggests that younger benefit recipients, who are also more involved in temporary jobs, are the most exposed to unemployment related poverty. It is very likely that this problem worsened during 2009. 


\section{Conclusion and policy lessons}

Our analysis finds large variation between EU Member States in their actual use of automatic stabilisers and discretionary fiscal stimuli with respect to social policy purposes. Furthermore, it is important to note that some social groups, such as young workers and those holding non-standard contracts, were particularly affected by a deterioration of labour market conditions. At the same time, however, they only have limited access to social benefits. In particular, unemployment benefits are sometimes found to be insufficient. This is particularly problematic if there is no effective minimum income support scheme. In fact, non-standard workers and younger labour market entrants experience a double disadvantage stemming from less stable jobs and less protection.

Taking an institutional point of view, we argue that automatic stabilisers inherent in unemployment and minimum income support schemes, but also short-time work allowances and progressive income taxation, can work without a significant time lag and also lead to timely phase out when the economy and the labour market recover. Unemployment benefits work as automatic stabilisers and can therefore act as major elements of stabilisation in the future as well. The same holds in particular for public short-time work subsidies which help stabilise employment and a trained workforce and thereby facilitate a dynamic economic development after crises. Hence, automatic stabilisers are of particular importance and should be developed, not in a uniform way, but taking into account the specific national economic and institutional context. Establishing a proper system of automatic stabilisers reduces the need for further discretionary action and avoids time lags inevitable in case of discretionary fiscal stimuli. They reduce the need for discretionary adjustment and help prepare for future volatilities.

Furthermore, policy-makers should now prepare social protection schemes for the future and overcome present inequality in social security. It is particularly important to ensure that non-standard workers, those with fixed-term contracts or only a short employment record, in particular young people and other labour market entrants, have access to sufficient social protection so that social exclusion is prevented. One element is the creation of general minimum income schemes for all working-age people. This should, of course, be based on a careful assessment regarding the appropriate benefit level and not lead to work disincentives. In order to avoid long-term benefit dependency through exclusion from work, proper activation measures have to be put in place including job search assistance and training. Furthermore, it should be checked whether and how access to unemployment insurance benefits can be made more general, in particular by assessing the role minimum employment or contribution conditions play in the case of young people, other labour market entrants and, in general, people on non-standard contracts. Some EU Member States have already moved in this direction. They should refrain from making unemployment benefits 
more exclusive again in the imminent phase of fiscal austerity but try to develop a sustainable and fair system of social protection.

Discretionary action should be well-targeted and timely, but also temporary. Hence, there is a need for a clear exit strategy in order to avoid the risk of ineffective spending of public resources through prolonged subsidisation and eventually pro-cyclical impacts. Growing fiscal constraints will otherwise hamper the capacity of governments to counter future economic uncertainties. As temporary measures quite often tend to be prolonged, it is important that policy-makers assess the need for discretionary measures carefully and check regularly the justification for their existence. A more rule-driven, quasi-'automatic' approach to discretionary action could be helpful in this respect, i.e. by referring to objective indicators when deciding on the introduction or maintenance of fiscal stimuli, in particular temporary social measures. A rulebased approach to discretionary spending could refer to the development of (nonsubsidised) employment, unemployment rates or to GDP - both current and forecast data.

Finally, labour market dualisms can only be overcome if the regulatory divide between different types of employment such as open-ended contracts, fixed-term jobs and agency work is mitigated, in particular with reference to models of a "unified employment contract" which would provide for a progressive amount of employment protection according to tenure. 


\section{Bibliography}

Aaberge, R., Björklund, A., Jäntti, M., Pedersen, P.J., Smith, N. and Wennemo, T. (2000), "Unemployment shocks and income distribution: How did the Nordic Countries fare during their crises?", Scandinavian Journal of Economics, 102(1), 77-99.

Abraham, K. and Houseman, S. (1994), "Does Employment Protection Inhibit Labor Market Flexibility? Lessons from Germany, France, and Belgium", in R. Blank (ed.), Social Protection versus Economic Flexibility: Is There a Trade-Off?, University of Chicago, 59-94.

Auerbach, A. and Feenberg, D. (2000), "The significance of federal taxes as automatic stabilizers", Journal of Economic Perspectives, 14(3), 37-56.

Bargain, O. Immervoll, H., Peichl, A. and Siegloch, S. (2011), "Distributional consequences of labordemand shocks: the 2008-2009 recession in Germany', International Tax and Public Finance, DOI 10.1007/s10797-011-9177-9.

Boeri, T. and Garibaldi, P. (2009), "Beyond Eurosclerosis", Economic Policy 59, 409-461.

Boeri, T. and Bruecker, H. (2011), "Short-Time Work Benefits Revisited: Some Lessons from the Great Recession", IZA Discussion Paper No 5635, Bonn: IZA.

Bourguignon, F. and Spadaro, A. (2006), "Microsimulation as a tool for evaluating redistribution policies", Journal of Economic Inequality, 4(1), 77-106.

Cahuc, P. and Carcillo, S. (2011), 'Is Short-time Work a Good Method to Keep Unemployment Down?'. CEPR Discussion Paper no. 8214. London, Centre for Economic Policy Research.

Cazes, S., Verick, S. and Heuer, C. (2009), "Labour market policies in times of crisis", Employment Working Paper No 35, Geneva: ILO.

D'Amuri, F. (2011), "The impact of the Great Recession on the Italian labour market", Research in Labour Economics 32, 155-180.

Dolls, M., Fuest, C. and Peichl, A. (2010), "Automatic stabilizers and economic crisis: US vs. Europe", NBER Working Paper No 16275.

Dolls, M., Fuest, C. and Peichl, A. (2011), "Automatic stabilizers, economic crisis and income distribution in Europe", Research in Labor Economics 32, 227-256.

Eaton, J. and Rosen, H.S. (1980), "Optimal redistributive taxation and uncertainty", Quarterly Journal of Economics, 95(2), 357-364.

Eichhorst, W., Dolls, M., Marx, P., Peichl, A., Devisscher, S., Leoni, T., Tockner, L., Marterbauer, M., Ederer, S., Basso, G., Gerard, M., Vanhoren, I., Nielsen, C., "The Role of Social Protection as an Economic Stabiliser: Lessons from the Current Crisis. Report based on a study conducted for the European Parliament", IZA Research Reports, Bonn, 2010, 31.

European Commission (2010), Taxation Trends in the EU: 2010 Edition, Luxembourg: EC.

Figari, F., Salvatori, A. and Sutherland, H. (2011), "Economic downturn and stress testing European welfare systems", Research in Labour Economics 32, 257-286.

Hijzen, A. and Venn, D. (2011), "The Role of Short-Time Work Schemes during the 2008-09 Recession", OECD Social, Employment and Migration Working Papers, No. 115.

IMF (2010), World Economic Outlook 2010, May, Berlin.

OECD (2009), Employment Outlook 2009: Tackling the job crisis, Paris: OECD.

OECD (2009b), Addressing the Labour Market Challenges of the Economic Downturn: A summary of country responses to the OECD-EC Questionnaire, Paris: OECD.

OECD (2010), Employment Outlook 2010, Paris: OECD.

OECD (2011a), OECD Ministerial Meeting on Social Policy, background document session 1: Economic crisis and beyond: Social policies for the recovery, Paris, 2-3 May.

OECD (2011b), Employment Outlook 2011, Paris: OECD. 